\title{
Proposal of Oscillochloridaceae fam. nov. on the basis of a phylogenetic analysis of the filamentous anoxygenic phototrophic bacteria, and emended description of Oscillochloris and Oscillochloris trichoides in comparison with further new isolates
}

\author{
Olga I. Keppen, ${ }^{1}$ Tatjana P. Tourova, ${ }^{2}$ Boris B. Kuznetsov, ${ }^{2}$ \\ Ruslan N. Ivanovsky ${ }^{1}$ and Vladimir M. Gorlenko ${ }^{2}$
}

Author for correspondence: Ruslan N. Ivanovsky. Tel: + 70959394203. Fax : + 70959394658.
e-mail: ruslan@protein.bio.msu.su

\footnotetext{
1 Department of Microbiology, Moscow State University, 119899 Moscow, Russia

2 Institute of Microbiology, Russian Academy of Sciences, pr. 60-letiya Oktyabrya 7 k.2, 117811 Moscow, Russia
}

\begin{abstract}
The nucleotide sequences of the genes of 16S rRNAs were determined for the type strain Oscillochloris trichoides DG- $6^{\top}$ and three new strains of Oscillochloris-like mesophilic filamentous green bacteria. Two major clusters have been found within the family Chloroflexaceae by phylogenetic analysis: one cluster includes thermophilic species of Chloroflexus and the second includes mesophilic strains of Oscillochloris. The degree of relatedness of these clusters was below an intergeneric level, having only $82.5-86.5 \%$ of 165 rDNA sequence similarity. These phylogenetic data correlate well with the significant physiological, biochemical and chemotaxonomical differences between members of both groups. Therefore, the Oscillochloris and Ch/oroflexus clusters should be considered as two separate families. The description of the new family, Oscillochloridaceae fam. nov., and emended descriptions of the genus Oscillochloris and the species Oscillochloris trichoides are presented.
\end{abstract}

Keywords: filamentous green bacteria, Oscillochloridaceae fam. nov., Oscillochloris trichoides, phylogenetic analysis, taxonomic revision

\section{INTRODUCTION}

The thermophilic filamentous green bacterium Chloroflexus aurantiacus (Pierson \& Castenholz, 1974) was the first-discovered genus and species of the family Chloroflexaceae. The new family Chloroflexaceae was proposed by Trüper (1976), on the basis of the properties of Chloroflexus aurantiacus, and placed in the suborder Chlorobiales. Trüper based his classification on a set of bacteriochlorophylls ( $c$ and $a$ ) and special antenna structures (chlorosomes). These properties, found in both $C$. aurantiacus and members of Chlorobiaceae, distinguished them from the purple phototrophic bacteria and the subsequently described

This paper is dedicated to the memory of Professor Elena N. Kondratieva (1925-1995).

The GenBank accession numbers of the 16S rDNA sequences of Oscillochloris trichoides strain DG- $6^{\top}$ and Oscillochloris strains $B M, A-19$ and $R$ are AF093427, AF149018, AF146831 and AF146832, respectively. heliobacteria. However, the bacteria consequently ascribed to the new family Chloroflexaceae showed substantial morphological and physiological differences. They form multicellular trichomes, have gliding motility and have flexible cell walls. They grow best as photoheterotrophs and are able to grow aerobically in darkness, they have a unique $\mathrm{CO}_{2}$ fixation pathway and they are incapable of nitrogen fixation, etc. Furthermore, the new family differed significantly from the previously known unicellular green sulfur bacteria of the family Chlorobiaceae (Pierson \& Castenholz, 1974, 1995). On the basis of a $16 \mathrm{~S}$ rRNA analysis, it was concluded that as all green sulfur bacteria and Chloroflexus-like organisms formed separate deep eubacterial lines of descent (Gibson et al., 1985; Woese, 1987; Stackebrandt et al., 1996), they could not belong to the same suborder.

All previous taxonomic descriptions of the family Chloroflexaceae have been based on the study of $C$. 
aurantiacus, the only species that had been successfully isolated and sustained in pure culture. However, additional filamentous phototrophic bacteria are now known. Pfennig (1989) grouped them as 'multicellular filamentous green bacteria' including the genera Chloroflexus, Chloronema, Oscillochloris and Heliothrix. Pierson \& Castenholz (1995) correctly noted that this name was not accurate, as Heliothrix, apparently different from the other species of the group, has only bacteriochlorophyll $a$ (not $c, d$ or $e$ ) and does not contain chlorosomes. These authors proposed that the group should be named 'anoxygenic filamentous phototrophic bacteria'. It should be mentioned that it is a very diverse group that comprises photoautotrophic and photoheterotrophic organisms with or without chlorosomes, facultative anaerobes and strict anaerobes, thermophilic and mesophilic bacteria and salt- and freshwater forms.

Most of the proposed 'species' have been studied as natural populations or in binary or mixed cultures (Gorlenko \& Korotkov, 1979; Pierson et al., 1994). Mesophilic freshwater strains of Chloroflexus-like bacteria isolated earlier (Gorlenko, 1975) were lost. Until recently, pure cultures were available only for some strains of C.aurantiacus. The description of the second thermophilic species of this genus, Chloroflexus aggregans (Hanada et al., 1995), did not lead to any essential changes in the characteristics of the family Chloroflexaceae. Therefore the taxonomy and phylogenetic position of filamentous anoxygenic phototrophic bacteria remains unclear. Consequently, broadly based phenotypic data and nucleic acid sequences are needed to construct useful taxa and meaningful phylogenies.

Research on the first pure culture of the mesophilic filamentous green bacterium Oscillochloris trichoides has been essential in expanding our knowledge of this bacterial group (Gorlenko \& Pivovarova, 1977; Gorlenko \& Korotkov, 1979; Keppen et al., 1989, 1993, 1994; Ivanovsky, 1993; Ivanovsky et al., 1999). The photosynthetic apparatus of $O$. trichoides DG- ${ }^{\mathrm{T}}$ as well as that of $C$. aurantiacus contains chlorosomes with bacteriochlorophylls $c$ and $\alpha$-, $\beta$ - and $\gamma$-carotenes as light-harvesting pigments. The in vivo absorption spectra of cell suspensions of $O$. trichoides DG- $6^{\mathrm{T}}$ exhibited maxima at 456,748 and $852 \mathrm{~nm}$. In contrast to $C$. aurantiacus, $O$. trichoides strain $\mathrm{DG}-6^{\mathrm{T}}$ performed autotrophic $\mathrm{CO}_{2}$ fixation using the reductive pentose phosphate cycle (the Calvin cycle), with ribulose 1,5-bisphosphate carboxylase and phosphoribulokinase as the key enzymes (Ivanovsky, 1993; Ivanovsky et al., 1999). The reductive tricarboxylic acid cycle typical of the green sulfur bacteria (Evans et al., 1966) was not found in O. trichoides. The 3-hydroxypropionate cycle (Strauss \& Fuchs, 1993) or reductive dicarboxylic acid cycle (Ivanovsky et al., 1993), proposed for C. aurantiacus strains OK-70fl and B-3, respectively, was not found in O. trichoides. Unlike C. aurantiacus (Krasilnikova et al., 1986), O. trichoides has a functionally incomplete tricarboxylic acid cycle lacking 2-oxoglutarate dehydrogenase and it lacks the glyoxylate bypass (Keppen \& Krasilnikova, 1995; Ivanovsky et al., 1999). O. trichoides DG-6 $6^{\mathrm{T}}$ can use only a limited number of organic compounds (acetate, pyruvate) for photolithoheterotrophic growth, whereas it is unable to grow as a chemoheterotroph under aerobic or microaerobic conditions in the dark (Keppen et al., 1994). DNA-DNA hybridization experiments indicate the existence of remote genetic relationships between $O$. trichoides DG$6^{\mathrm{T}}$ and $C$. aurantiacus (less than $5 \%$ homology). $5 \mathrm{~S}$ rRNA sequence analysis supported the fact that they form a monophyletic group (Keppen et al., 1994). Thus, phenotypic and genotypic differences between species of the genera Chloroflexus and Oscillochloris were substantial enough to allow the proposal that Oscillochloris represents an independent family.

To establish the phylogenetic position of the genus Oscillochloris, we have undertaken a sequence analysis of $16 \mathrm{~S}$ rDNA genes of strain DG-6 $6^{\mathrm{T}}$ of $O$. trichoides and three new strains of Oscillochloris spp. which had been isolated from different environments. On the basis of the phylogenetic data and the unique physiological properties of the studied strains of Oscillochloris, we propose the family Oscillochloridaceae fam. nov.

\section{METHODS}

Strains and growth conditions. Four strains of mesophilic filamentous green bacteria were isolated and studied in pure culture. O. trichoides strain DG- $6^{\mathrm{T}}$ was isolated from microbial mats of warm hydrogen sulfide springs in the Caucasus region of SE Europe (Keppen et al., 1993, 1994). Strain $\mathrm{R}$ was isolated from shallow river waters near Moscow (the Moscow River), strain BM was from a littoral estuary of the White Sea (Nilma Guba) and strain A-19 was from an alkaline soda lake (Lake Gonzogor; $\mathrm{pH} 9 \cdot 3$, total dissolved salts $0.9 \mathrm{~g}^{-1}$ ) in SE Siberia. The thermophilic filamentous green bacterium C. aurantiacus (strain OK-70fl) was used for comparative studies.

All strains were maintained on modified medium DGN (Castenholz \& Pierson, 1981; Keppen et al., 1994). For strain A-19, the $\mathrm{pH}$ was adjusted to 9.0 by the addition of $\mathrm{NaHCO}_{3}\left(2 \cdot 5 \mathrm{~g} \mathrm{l}^{-1}\right)$ and $\mathrm{Na}_{2} \mathrm{CO}_{3}\left(2 \cdot 5 \mathrm{~g} \mathrm{l}^{-1}\right)$. The organisms were routinely cultivated at $1000 \mathrm{~lx}$ in $100 \mathrm{ml}$ screw-cap bottles completely filled with the medium. The inoculum was $10-15 \%(\mathrm{v} / \mathrm{v})$ and the bottles were incubated at $28^{\circ} \mathrm{C}$ for mesophilic species and at $55^{\circ} \mathrm{C}$ for C. aurantiacus.

Fatty acids and quinone composition. The fatty acids were analysed as described previously (Zhilina et al., 1997), using a Hewlett Packard HP-5973 mass spectrometer. The quinones were assayed according to Collins (1985), using a Finnigan MAT 8430 mass spectrometer.

$16 \mathrm{~S}$ rRNA sequencing and analysis. The $16 \mathrm{~S}$ rRNA gene was selectively amplified from genomic DNA by the PCR, using 5'-AGAGTTTGATCCTGGCTCAG-3' as the forward primer and 5'-TACGGTTACCTTGTTACGACTT-3' as the reverse one (Lane, 1991). The PCR was performed in $100 \mu \mathrm{l}$ reaction mixture, which consisted of $1 \mu \mathrm{g}$ DNA template, $200 \mu \mathrm{M}$ (each) primers, $200 \mu \mathrm{M}$ (each) deoxynucleoside triphosphates and $3 \mathrm{U}$ Tet-z polymerase 
(BioMaster) in reaction buffer $(100 \mathrm{mM}$ Tris/ $\mathrm{HCl}, 500 \mathrm{mM}$ $\mathrm{KCl}, 20 \mathrm{mM} \mathrm{MgCl}{ }_{2} ; \mathrm{pH} \mathrm{8.3)}$. The temperature cycling was done in 30 amplification cycles: $1 \mathrm{~min}$ at $94{ }^{\circ} \mathrm{C}, 1 \mathrm{~min}$ at $42{ }^{\circ} \mathrm{C}$ and $1 \mathrm{~min}$ at $72{ }^{\circ} \mathrm{C}$. The final extension was performed at $72{ }^{\circ} \mathrm{C}$ for $6 \mathrm{~min}$. The PCR products were purified with the PCR prep kit (Promega), as recommended by the manufacturer. The 16S rRNA gene was sequenced in both directions with the forward and reverse primers. DNA sequencing was performed with Sequenase version 2 from USB. The 16S rDNA sequence was aligned with the sets of 16S rRNA sequences, which had been obtained from either the most recent versions of the Ribosomal Database Project or from GenBank, by using MULTALIN software (Corpet, 1988). Phylogenetic dendrograms were constructed by treeing algorithms from the GENEBEE package (Brodsky et al., 1991), the PHYLIP package (Felsenstein, 1989) and the TREECON package (Van de Peer \& De Wachter, 1994).

Nucleotide sequence accession numbers. The accession numbers of the sequences used as references were as follows: C. aurantiacus $\mathrm{J}-10-\mathrm{fl}^{\mathrm{T}}$, M34116; C. aurantiacus Y400-fl, L05508, L05509, L05510, L04674; C. aggregans MD-66 ${ }^{\mathrm{T}}$, D32255; Herpetosiphon aurantiacus ATCC 23779 ${ }^{\mathrm{T}}$, M34117; Herpetosiphon sp. F018, X86447; Herpetosiphon geysericola ATCC 23076 ${ }^{\mathrm{T}}$, AF039293; Heliothrix oregonensis $\mathrm{F}^{\mathrm{T}}$, L04675; Thermomicrobium roseum ATCC 27502 ${ }^{\mathrm{T}}$, M34115; Sphaerobacter thermophilus S $6022^{\mathrm{T}}$, X53210; Dehalococcoides ethenogenes 195 ${ }^{\mathrm{T}}$, AF004928; Thermus aquaticus YT-1 ${ }^{\mathrm{T}}$, L09663; Meiothermus ruber ATCC $35948^{\mathrm{T}}$, Z15059; Deinococcus radiodurans ATCC $35073^{\mathrm{T}}$, M21413; Chlorobium limicola 8327, M31769.

\section{RESULTS AND DISCUSSION}

\section{Characteristics of Oscillochloris strains}

All of the strains of mesophilic filamentous green bacteria studied were grown in the light under anaerobic conditions only. Strains R, BM and A-19 were morphologically similar to $O$. trichoides DG-6 ${ }^{\mathrm{T}}$ (Keppen et al., 1994). They all had green, flexible, gliding, non-ramified multicellular filaments, 1.0$1.5 \mu \mathrm{m}$ in diameter, with or without sheaths. The lengths of the individual cells in filaments varied from 2.0 to $5.0 \mu \mathrm{m}$. The cells usually contained gas vesicles, which were localized along the cell septa. The bacteria deposited poly- $\beta$-hydroxybutyrate inside the cells. Globules and crystals of sulfur were deposited outside the cells in the immediate proximity of the trichomes. Cell suspensions were dark green. Chlorosomes served as light-harvesting structures of the photosynthetic apparatus. Bacteriochlorophyll $c$ was the major photosynthetic pigment. A small amount of bacteriochlorophyll $a$ was also present.

The preferred mode of growth was photolithoheterotrophic, but strains were also able to grow photoautotrophically with sulfide as an electron donor and $\mathrm{CO}_{2}$ as the sole carbon source. All of these strains oxidized sulfide only to elemental sulfur. They were mesophilic, with optimal growth at $28-30^{\circ} \mathrm{C}$. Strains exhibited growth at $\mathrm{pH} 6 \cdot 8-9 \cdot 0$, with the optimum at $\mathrm{pH} 7 \cdot 5-8 \cdot 5$. The optimal concentration of sulfide $\left(\mathrm{Na}_{2} \mathrm{~S} .9 \mathrm{H}_{2} \mathrm{O}\right)$ was $0 \cdot 5-0.7 \mathrm{~g} \mathrm{l}^{-1}$. Sulfide was tolerated at levels up to $1.5 \mathrm{~g}^{-1}$.
Table 1. Fatty acid composition of Oscillochloris trichoides DG-6 ${ }^{\top}$ and Chloroflexus aurantiacus OK-70fI

\begin{tabular}{|rlrr|}
\hline & Fatty acid & DG-6 & OK-70fl \\
\hline 1. & $14: 0$ & $0 \cdot 31$ & $0 \cdot 12$ \\
2. & $15: 0$ & $0 \cdot 23$ & $1 \cdot 08$ \\
3. & $15 \mathrm{alk}$ & $0 \cdot 25$ & $0 \cdot 06$ \\
4. & $16: 1$ & $15 \cdot 93$ & $1 \cdot 01$ \\
5. & $16: 0$ & $30 \cdot 33$ & $19 \cdot 23$ \\
6. & $16 \mathrm{alk}$ & $9 \cdot 65$ & $1 \cdot 56$ \\
7. & $\mathrm{~h} 16$ & $0 \cdot 61$ & $0 \cdot 00$ \\
8. & $17: 1$ & $0 \cdot 23$ & $1 \cdot 43$ \\
9. & $17: 0$ & $0 \cdot 42$ & $7 \cdot 75$ \\
10. & $17 \mathrm{alk}$ & $0 \cdot 00$ & $0 \cdot 89$ \\
11. & $18: 1$ & $38 \cdot 28$ & $13 \cdot 86$ \\
12. & $18: 0$ & $2 \cdot 74$ & $30 \cdot 61$ \\
13. & 18 alk & $1 \cdot 02$ & $9 \cdot 63$ \\
14. & $19: 1$ & $0 \cdot 00$ & $1 \cdot 93$ \\
15. & $19: 0$ & $0 \cdot 00$ & $6 \cdot 31$ \\
16. & $19 \mathrm{alk}$ & $0 \cdot 00$ & $1 \cdot 68$ \\
17. & $20: 1$ & $0 \cdot 00$ & $1 \cdot 65$ \\
18. & $20: 0$ & $0 \cdot 00$ & $1 \cdot 20$ \\
\hline
\end{tabular}

Strains $\mathrm{BM}$ and $\mathrm{R}$, as well as $O$. trichoides DG- $6^{\mathrm{T}}$, assimilate $\mathrm{CO}_{2}$ via the Calvin cycle. They lack a complete TCA cycle and a glyoxylate bypass, can use only a limited number of organic compounds (acetate, pyruvate) for photolithoheterotrophic growth and are unable to grow as chemoheterotrophs under aerobic or microaerobic conditions in the dark.

\section{Fatty acids and quinone composition}

The fatty acid composition of $O$. trichoides DG- $6^{\mathrm{T}}$ and C. aurantiacus OK-70fl, as well as that of other phototrophic bacteria, was characterized by the predominance of C-16 and C-18 fatty acids (Table 1). However, detailed study revealed significant qualitative and quantitative differences in fatty acid composition between $O$. trichoides DG- $6^{\mathrm{T}}$ and $C$. aurantiacus OK-70fl. Unlike C. aurantiacus OK-70fl, $O$. trichoides DG- $6^{\mathrm{T}}$ contained an 18:1 (38\%) component with a large amount of C-16 (56\%), whereas $C$. aurantiacus $\mathrm{OK}-70 \mathrm{fl}$ contained $\mathrm{C}-18$ fatty acids in higher proportions ( $54 \%$ ) than C-16 fatty acids $(22 \%)$. The relative concentrations of $17: 1$ and 17:0 in $O$. trichoides were much lower than in C.aurantiacus, and $\mathrm{C}: 17$ alk was not detected. In addition, $O$. trichoides DG- $6^{\text {T }}$ was unable to synthesize C-19 and C-20 fatty acids. The ratio of saturated to unsaturated fatty acid in O. trichoides DG-6 ${ }^{\mathrm{T}}(0 \cdot 84)$, as compared to that of phototrophic purple and green sulfur bacteria (0.9$1 \cdot 2)$, revealed significant differences as compared with thermophilic Chloroflexaceae species (3.6-3.8) and with Heliobacterium and Heliobacillus $(0 \cdot 2-0 \cdot 3)$ (Imhoff, 1988; Imhoff \& Bias-Imhoff, 1995).

On the whole, the comparison of our fatty acid composition data with the results obtained for other 


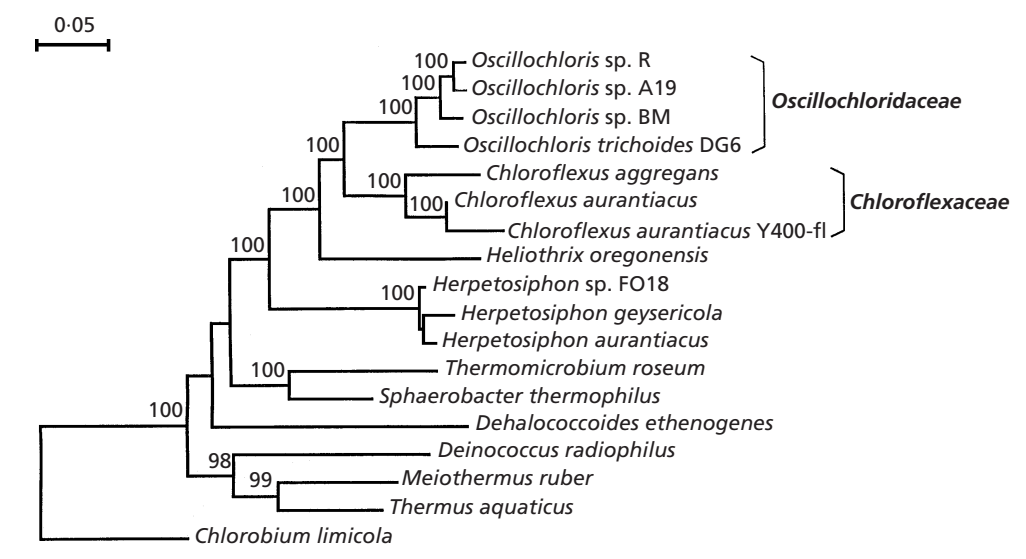

Fig. 1. Phylogenetic dendrogram of the
phylum 'green non-sulfur bacteria and their
relatives' based on the results of rDNA
sequence comparisons. Pairwise similarity
values were corrected according to Jukes \&
Cantor (1969) and used to reconstruct a
neighbour-joining tree (Saitou \& Nei, 1987).
Bootstrap values (expressed as percentages
of 100 replications) are shown at branch
points; values greater than 95 were
considered significant. Bar represents 5
nucleotide substitutions per 100 nucleotides.

phototrophic bacteria (Imhoff, 1988; Imhoff \& BiasImhoff, 1995) shows that the fatty acid composition of $O$. trichoides, while different from that of heliobacteria, members of the Chlorobiaceae or thermophilic members of the Chloroflexaceae, is similar to that of some purple bacteria.

Menaquinone (MK-10) was the only quinone found in both $O$. trichoides DG-6 ${ }^{\mathrm{T}}$ and $C$. aurantiacus.

\section{Analysis of $16 \mathrm{~S}$ rDNA sequence data}

The almost complete 16S rDNA sequences (nearly 1400 nucleotides long) were determined for the strain $O$. trichoides $\mathrm{DG}-6^{\mathrm{T}}$ and for three new isolates (BM, A-19 and $\mathrm{R}$ ). The $\mathrm{G}+\mathrm{C}$ contents of these sequences were $60 \cdot 4-61 \cdot 3 \mathrm{~mol} \%$. On the basis of the phenotypic analysis and the 5S rRNA sequences (Keppen et al., 1994), O. trichoides belongs to the eubacterial line of descent, formerly known as the 'green non-sulfur bacteria and their relatives', which lacked adequate phenotypic justification (Woese, 1987). This phylum contains two thermophilic green filamentous gliding phototrophs, $C$. aurantiacus and $C$. aggregans, the filamentous gliding non-photosynthetic bacterium $H$. aurantiacus and the unicellular non-photosynthetic thermophilic species $T$. roseum and $S$. thermophilus (Stackebrandt et al., 1996).

Recently, a new bacterium, Dehalococcoides ethenogenes, was described which reductively dechlorinates tetrachloroethene to ethane. This bacterium may also be distantly related to the phylum (Maymo-Gatell et al., 1997). Some micro-organisms, previously studied as natural populations, also belong to this phylum. These include a thermophilic filamentous gliding phototroph, H. oregonensis, which, unlike Chloroflexus and Oscillochloris, lacks chlorosomes and bacteriochlorophylls $c, d$ or $e$ (Weller et al., 1992), as well as certain environmental clones of uncultured eubacteria (Weller et al., 1991, 1992; Ward et al., 1992; Giovannoni et al., 1996; Ferris et al., 1996). The Deinococcus-Thermus line of descent is the one most closely related to this phylum.

The lineage of the 'green non-sulfur bacteria' is dominated by thermophilic species. The $\mathrm{G}+\mathrm{C}$ con- tents of the rRNAs, like that in other thermophilic prokaryotes (Achenbach-Richter et al., 1987; Murzina et al., 1988), tend to range from 58 to $66 \mathrm{~mol} \%$, while typical mesophillic bacterial rRNAs usually have $\mathrm{G}+\mathrm{C}$ contents of approximately $55 \%$. Despite the fact that the Oscillochloris strains are mesophilic, the $\mathrm{G}+\mathrm{C}$ contents of their $16 \mathrm{~S}$ rDNA sequences fell into the range typical for the phylum, i.e. $60 \cdot 4-61 \cdot 3 \mathrm{~mol} \%$. Thus, a phylogenetic tree inferred from a transversion analysis (Swofford \& Olsen, 1990; Woese et al., 1991), does not contradict the inferred normal analysis, excluding the instability of the $D$. ethenogenes ( $51.9 \mathrm{~mol} \% \mathrm{G}+\mathrm{C}$ in the $16 \mathrm{~S}$ rDNA sequence) branching point (data not shown). It can be suggested that the members of the genus Oscillochloris had thermophilic ancestors that adapted to temperate or even cold (White Sea) habitats.

For many organisms of the phylum 'green non-sulfur bacteria and their relatives' only partial sequences of $16 \mathrm{~S}$ rRNA are known. For phylogenetic analysis, therefore, we used several sets of sequences of $16 \mathrm{~S}$ rDNA containing the most complete sequences (more than 1400 nucleotides) and different parts of the sequences. Sequence analysis included a 'maximum topological similarity' algorithm (Chumakov \& Yushmanov, 1988), neighbour-joining (Saitou \& Nei, 1987 ) and the maximum-parsimony analysis and distance matrix algorithm of De Soete (1983). All methods produced very similar patterns of relatedness and tree topologies.

On the phylogenetic tree (Fig. 1), the Oscillochloris strains clearly belong to the phylum of 'green nonsulfur bacteria and their relatives' $(69 \cdot 2-86 \cdot 5 \%$ sequence similarity) with a high level of bootstrap probability. This is supported by the presence of all of the distinctive 'signatures' and 16S rRNA structural idiosyncrasies specific to this phylum (Woese, 1987). The new strains (R, BM and A-19) form a distinct genomic group (97.0-98.5\% sequence similarity). The sequence similarity between the new strains of Oscillochloris and $O$. trichoides strain DG-6 $6^{\mathrm{T}}$ was $93 \cdot 9-94 \cdot 4 \%$. Taking into account the low level of sequence similarity between the new strains and $O$. trichoides DG$6^{\mathrm{T}}$, they may be described in future as new species of 
Table 2. Sequence 'signatures' of $16 \mathrm{~S}$ rRNA-differentiated Oscillochloris, Chloroflexus and other members of the phylum 'green non-sulfur bacteria and relatives'

Base pairing (:) was deduced from secondary-structure assignment. Lower-case letters indicate bases found in less than $50 \%$ of assayable cases.

\begin{tabular}{|c|c|c|c|}
\hline \multirow[t]{2}{*}{ Sequence position* } & \multicolumn{3}{|c|}{ Corresponding bases } \\
\hline & Oscillochloris spp. & Chloroflexus spp. & $\begin{array}{l}\text { Common to other } \\
\text { members of phylum } \dagger\end{array}$ \\
\hline $131: 231$ & $\mathrm{U}: \mathrm{A}$ & $\mathrm{C}: \mathrm{G}$ & $\mathrm{C}: \mathrm{G}$ \\
\hline $138: 225$ & $\mathrm{U}: \mathrm{A}$ & $\mathrm{C}: \mathrm{G}$ & $\mathrm{C}(\mathrm{g}): \mathrm{G}(\mathrm{c})$ \\
\hline $139: 224$ & $C: G$ & $\mathrm{G}: \mathrm{C}(\mathrm{u})$ & $\mathrm{G}, \mathrm{U}: \mathrm{U}(\mathrm{c}, \mathrm{g})$ \\
\hline $140: 223$ & $\mathrm{~A}: \mathrm{U}$ & $\mathrm{G}: \mathrm{C}$ & $\mathrm{G}(\mathrm{a}): \mathrm{C}(\mathrm{u})$ \\
\hline 152 & A & $\mathrm{C}$ & $\mathrm{A}(\mathrm{g})$ \\
\hline $154: 167$ & $\mathrm{U}(\mathrm{g}): \mathrm{A}$ & $C: G$ & $\mathrm{G}(\mathrm{c}, \mathrm{u}): \mathrm{C}(\mathrm{g}, \mathrm{a})$ \\
\hline $157: 164$ & $\mathrm{G}: \mathrm{C}$ & $\mathrm{U}: \mathrm{A}$ & $\mathrm{G}, \mathrm{U}(\mathrm{c}): \mathrm{U}, \mathrm{A}(\mathrm{g})$ \\
\hline 166 & A & $\mathrm{G}$ & $\mathrm{U}(\mathrm{g}, \mathrm{a})$ \\
\hline 169 & $\mathrm{C}$ & A & $\mathrm{C}(\mathrm{g})$ \\
\hline $291: 309$ & $\mathrm{U}: \mathrm{A}$ & $C: G$ & $\mathrm{U}: \mathrm{A}$ \\
\hline 412 & $\mathrm{U}$ & $\mathrm{C}$ & $\mathrm{U}(\mathrm{g})$ \\
\hline $443: 491$ & $\mathrm{U}: \mathrm{G}$ & $\mathrm{G}: \mathrm{C}$ & $\mathrm{G}(\mathrm{c}): \mathrm{U}(\mathrm{g})$ \\
\hline 493 & $\mathrm{C}$ & A & $\mathrm{C}(\mathrm{g})$ \\
\hline $514: 537$ & $C: G$ & $\mathrm{U}: \mathrm{A}$ & $\mathrm{C}: \mathrm{G}$ \\
\hline 560 & $\mathrm{C}$ & $\mathrm{G}$ & $\mathrm{A}, \mathrm{G}(\mathrm{u})$ \\
\hline $579: 762$ & $\mathrm{~A}: \mathrm{U}$ & $\mathrm{G}: \mathrm{C}$ & $\mathrm{G}: \mathrm{C}$ \\
\hline $592: 647$ & $\mathrm{U}: \mathrm{A}$ & $\mathrm{G}: \mathrm{U}(\mathrm{c})$ & $\mathrm{A}(\mathrm{c}, \mathrm{g}, \mathrm{u}): \mathrm{U}(\mathrm{g}, \mathrm{c})$ \\
\hline $615: 625$ & $\mathrm{~A}: \mathrm{U}$ & $C: G$ & $\mathrm{C}, \mathrm{G}(\mathrm{a}): \mathrm{G}, \mathrm{C}(\mathrm{u})$ \\
\hline $668: 738$ & $\mathrm{~A}(\mathrm{~g}): \mathrm{U}$ & $\mathrm{G}: \mathrm{C}$ & $\mathrm{A}(\mathrm{c}): \mathrm{U}(\mathrm{g})$ \\
\hline 686 & $\mathrm{U}$ & $\mathrm{G}$ & $\mathrm{U}$ \\
\hline 721 & $\mathrm{U}$ & G(a) & $\mathrm{A}(\mathrm{g})$ \\
\hline 811 & $\mathrm{U}$ & $\mathrm{C}$ & $\mathrm{A}(\mathrm{g}, \mathrm{c})$ \\
\hline $824: 877$ & $\mathrm{~A}: \mathrm{U}$ & $\mathrm{G}: \mathrm{C}$ & $\mathrm{U}(\mathrm{g}, \mathrm{c}): \mathrm{A}(\mathrm{c}, \mathrm{g})$ \\
\hline 831 & $\mathrm{U}$ & $\mathrm{C}$ & $\mathrm{U}$ \\
\hline 859 & A & $\mathrm{U}$ & $\mathrm{C}(\mathrm{a}, \mathrm{g})$ \\
\hline 1059: 1198 & $\mathrm{U}: \mathrm{A}(\mathrm{g})$ & $C: G$ & $C: G$ \\
\hline $1115: 1185$ & $\mathrm{C}: \mathrm{G}$ & $\mathrm{G}: \mathrm{C}$ & $C: G$ \\
\hline $1118: 1155$ & $C: G$ & $\mathrm{U}: \mathrm{A}$ & $\mathrm{U}(\mathrm{g}): \mathrm{A}(\mathrm{c})$ \\
\hline 1159 & A & $\mathrm{U}$ & $\mathrm{U}$ \\
\hline 1297 & $\mathrm{C}$ & $\mathrm{U}$ & $\mathrm{A}(\mathrm{u}, \mathrm{g})$ \\
\hline
\end{tabular}

* Numbering is according Escherichia coli nomenclature.

$\dagger$ All 16S rRNA sequences of 'green non-sulfur bacteria and relatives' are from the most recent versions of the Ribosomal Database Project and GenBank.

the genus Oscillochloris. However, additional phenotypic studies are necessary.

The Oscillochloris strains showed only remote relatedness with non-phototrophic members of the phylum (69-2-76.6\% sequence similarity). The phototrophic genera Oscillochloris, Chloroflexus and Heliothrix formed a monophyletic cluster in which the highest level of sequence similarity was found between branches of Chloroflexus and Oscillochloris (82.5$86.5 \%$ ). However, a similar level of sequence similarity had been shown for members of related families: for example, Chromatiaceae and Ectothiorhodospiraceae have $84-90 \%$ similarity (Imhoff \& Suling, 1996) and
Haloanaerobiaceae and Halobacteroidaceae show 82$85 \%$ similarity (Rainey et al., 1995). In our opinion, the level of sequence divergence of $O$. trichoides DG- $6^{\mathrm{T}}$ as well as the new isolates and other phototrophic genera of the phylum corresponds to an interfamiliar one.

More detailed analysis of the 16S rDNA sequences produced 'signatures' of base substitutions that delineated the Oscillochloris and Chloroflexus phylogenetic clusters (Table 2). The secondary-structure analysis shows that most of these changes occurred in helices and involved paired bases (compensatory substitutions). Moreover, the Oscillochloris and other 
Table 3. Comparative characteristics of $O$. trichoides DG- $6^{\top}$ and $C$. aurantiacus $\mathrm{OK}-70 \mathrm{fl}$

\begin{tabular}{|c|c|c|}
\hline Characteristic & Oscillochloris trichoides & Chloroflexus aurantiacus \\
\hline Cell diameter $(\mu \mathrm{m})$ & $0 \cdot 8-1 \cdot 0$ & $0 \cdot 5-1 \cdot 0$ \\
\hline Motility & Gliding & Gliding \\
\hline Sheath & + & $+/-$ \\
\hline Gas vesicles & + & - \\
\hline Chlorosomes & + & + \\
\hline Colour of culture & Green & Orange-green \\
\hline Bacteriochlorophylls & $c, a$ & $c, a$ \\
\hline IR max. of bacteriochlorophylls & 748,852 & $750,805,860$ \\
\hline Major carotenoids & $\beta$-Carotene and $\gamma$-carotene & $\beta$-Carotene and $\gamma$-carotene \\
\hline Optimum pH & $8 \cdot 0-8 \cdot 5$ & $7 \cdot 0-7 \cdot 8$ \\
\hline Temperature category & Mesophilic & Thermophilic \\
\hline Photolithoautotrophy & + & + \\
\hline $\begin{array}{l}\text { Autotrophic } \mathrm{CO}_{2} \text {-fixation } \\
\text { pathway }\end{array}$ & Calvin cycle & 3-Hydroxypropionate cycle \\
\hline Electron donors & $\mathrm{H}_{2}, \mathrm{~S}^{2-}$ & $\mathrm{H}_{2}, \mathrm{~S}^{2-}$ \\
\hline Oxidation products of sulfide & $\mathrm{S}^{0}$ & $\mathrm{~S}^{0}$ \\
\hline $\begin{array}{l}\text { Carbon compounds } \\
\text { photometabolized }\end{array}$ & Acetate, pyruvate & $\begin{array}{l}\text { Wide range of organic } \\
\text { substrates }\end{array}$ \\
\hline Tricarboxylic acid cyle & - & + \\
\hline Glyoxylate shunt & - & + \\
\hline Assimilatory sulfate reduction & - & + \\
\hline Reserve compounds & $\begin{array}{l}\text { Poly- } \beta \text {-hydroxybutyrate, } \\
\text { polyphosphate }\end{array}$ & $\begin{array}{l}\text { Poly- } \beta \text {-hydroxybutyrate, } \\
\text { polyphosphate }\end{array}$ \\
\hline Saturated/unsaturated fatty acid & $0 \cdot 63$ & $3 \cdot 3-3 \cdot 8$ \\
\hline Major quinone & MK-10 & MK-10 \\
\hline $\mathrm{N}_{2}$ fixation & + & - \\
\hline DNA G + C content $(\mathrm{mol} \%)$ & $59 \cdot 2$ & $57 \cdot 6$ \\
\hline $16 \mathrm{~S}$ rDNA $\mathrm{G}+\mathrm{C}$ content $(\mathrm{mol} \%)$ & $60 \cdot 4-61 \cdot 3$ & $62 \cdot 8-63 \cdot 9$ \\
\hline
\end{tabular}

phototrophic branches of the dendrogram should be characterized by specific versions of regions corresponding to positions $70-100,820-880$ and $1149-1180$ of Escherichia coli.

Taking into account the deep branching point of organisms of the genus Oscillochloris within the 'green non-sulfur bacteria and their relatives' phylum and the fact that they are well defined phenotypically and phylogenetically, we propose the family Oscillochloridaceae fam. nov. with a single genus, Oscillochloris, for mesophilic filamentous gliding phototrophic bacteria. Table 3 summarizes the main properties of $O$. trichoides DG- $6^{\mathrm{T}}$ and $C$. aurantiacus $\mathrm{OK}-70 \mathrm{fl}$.

Therefore, we propose the following taxonomic changes:

1. To create the new family Oscillochloridaceae with the type genus Oscillochloris.

2. To emend the description of the genus Oscillochloris.

3. To emend the description of the species Oscillochloris trichoides; according to Rules $18 \mathrm{a}$ and $18 \mathrm{f}$ of the International Code of Nomenclature of Bacteria (Lapage et al., 1992), to designate strain DG-6 ${ }^{\mathrm{T}}$ as the type strain of Oscillochloris trichoides, instead of the description used before as the type strain of this species.

\section{Description of Oscillochloridaceae fam. nov.}

Oscillochloridaceae (Os.cil.lo.chlo.ri.da'ceae. L. part. adj. oscillans oscillating; Gr. adj. chloros green; M.L. fem. pl. n. Oscillochloridaceae taxonomic family name of the oscillating green bacteria).

Cells are arranged in multicellular flexible filaments, of constant diameters, with gliding motility. The trichomes do not form branches and are uniformly wide throughout their length. The length of trichomes is variable, with or without sheaths. Trichomes multiply by the separation of short segments or single cells from the parental trichome. Cells may contain gas vesicles. Trichomes appear green or yellowish-green. The cells contain bacteriochlorophylls $c$ and $a$ as well as carotenoid pigments. The light-harvesting structures of the photosynthetic apparatus are chlorosomes. Photolithoautotrophic or photolithoheterotrophic under anoxic conditions. Some strains are capable of growth under microaerobic conditions. All known species are mesophilic. The differences in the sequences of $16 \mathrm{~S}$ rRNA between members of the 
families Oscillochloridaceae and Chloroflexaceae are in the range $13 \cdot 5-17 \cdot 5 \%$. The type genus is Oscillochloris (Gorlenko and Pivovarova 1977, 1989).

\section{Emended description of the genus Oscillochloris (Gorlenko and Pivovarova 1977, 1989).}

Oscillochloris [Os.cil'lo.chlo'ris. L. part. adj. oscillans oscillating; Gr. adj. chloros green; M.L. fem. n. Oscillochloris oscillating green (bacterium)].

Cells are arranged in uniseriately multicellular flexible filaments with gliding motility. Trichomes are uniformly wide throughout their length, length-variable, non-branching and are with or without sheaths. Trichomes multiply by the separation of short segments or single cells from the parental trichome. Cells usually contain gas vesicles. Cells stain Gram-positive or Gram-negative. Trichomes appear green or yellowgreen. The cells contain bacteriochlorophylls $c$ and $a$ as well as carotenoids. The light-harvesting structures of the photosynthetic apparatus are chlorosomes. All known species are mesophiles. Photolithoheterotrophic or photolithoautotrophic under anaerobic conditions; capable of photosynthesis in the presence of hydrogen sulfide, during which they deposit elemental sulfur globules outside the cells. Some strains are capable of growth under microaerobic conditions. The $\mathrm{G}+\mathrm{C}$ content of the DNA of Oscillochloris chrysea was not determined. For $O$. trichoides strain DG-6 ${ }^{\mathrm{T}}$, the $\mathrm{G}+\mathrm{C}$ content of the DNA is $57 \cdot 3-59 \cdot 2 \mathrm{~mol} \%$ (melting point). The type species is Oscillochloris chrysea (Gorlenko and Pivovarova 1977, 1989).

\section{Emended description of Oscillochloris trichoides [Gorlenko and Korotkov 1979, 1989; Oscillatoria trichoides (Szafer) Lauterborn 1915]}

Oscillochloris trichoides (tri.cho'i.des. Gr. adj. trichoides hair-like).

Trichomes are straight or wave-like, green and $0 \cdot 8$ $1.4 \mu \mathrm{m}$ wide. Individual cells in filaments vary in length from 2.0 to $5.0 \mu \mathrm{m}$. There may or may not be a thin sheath or trichomes are surrounded by a thin slime layer. Cells are motile by slow gliding at a rate of $0 \cdot 2 \mu \mathrm{m} \mathrm{s}^{-1}$ and multiply by separation of a short section of the filament or of an individual cell from the parental trichome. In older cultures, gas vesicles are formed along the cell septa. The light-harvesting structures are chlorosomes. Bacteria deposit poly- $\beta$ hydroxybutyrate inside the cells. Strain DG- $6^{\mathrm{T}}$ is strictly anaerobic and obligately phototrophic. Cell suspensions appear dark green when grown under anaerobic conditions in the light. Some strains can grow under microaerobic conditions and appear orange. The in vivo absorption spectra of cell suspensions have maxima at 333, 456, (520), 748 and $852 \mathrm{~nm}$. The major photosynthetic pigment is bacteriochlorophyll $c$; a small amount of bacteriochlorophyll $a$ is also present. The major carotenoid pigments are $\beta$-carotene and $\gamma$-carotene. Strain DG- $6^{\mathrm{T}}$ contains menaquinone (MK-10) as the only quinone. Mesophilic, with optimal growth at $28-30^{\circ} \mathrm{C}$. Cells grow at $\mathrm{pH} 6 \cdot 8-9 \cdot 0$, with an optimum at $\mathrm{pH} 8 \cdot 0-8 \cdot 5$. Growth under photolithoautotrophic conditions can be detected in the presence of sulfide and/or molecular hydrogen as the electron donors. The optimal concentration of sulfide $\left(\mathrm{Na}_{2} \mathrm{~S} .9 \mathrm{H}_{2} \mathrm{O}\right)$ is $0.5-0.7 \mathrm{~g} \mathrm{l}^{-1}$. Cells are tolerant to sulfide at concentrations up to $1.5 \mathrm{~g}^{-1}$. Cells oxidize sulfide to elemental sulfur, which is deposited outside the cells. Carbon dioxide fixation proceeds via the Calvin cycle. Cells grow preferentially on medium containing acetate, pyruvate, casein hydrolysate or yeast extract in addition to bicarbonate and sulfide. Formate, propionate, butyrate, malate, succinate, fumarate, citrate and benzoate do not sustain growth. The TCA cycle is truncated, lacking 2-oxyglutarate dehydrogenase. The key enzyme of the glyoxylate bypass (isocitrate lyase) is absent. Sulfide, cysteine, cystine and sulfur, but not sulfate, can be used as sulfur sources. The cells use ammonium salts, urea, glycine, glutamate, glutamine, asparagine and casein hydrolysate as nitrogen sources. The capacity of the strain DG- $6^{\mathrm{T}}$ to fix molecular nitrogen was confirmed by the ability of the cell suspension to reduce acetylene. Yeast extract or a mixture of vitamins (thiamin, biotin, riboflavin and folic acid) is required for growth. The habitat is mats on the surface of sulfide-containing mud in freshwater pools and springs. In the environment, these species coexist with other anoxygenic phototrophic micro-organisms (Chlorobium sp., Allochromatium and Thiocapsa species) and cyanobacteria (Oscillatoria and Pseudanabaena species). The G $+\mathrm{C}$ content of the DNA of the type strain is $59 \cdot 2 \mathrm{~mol} \%$ (melting point). The type strain is DG-6 ${ }^{\mathrm{T}}$ (= VKM B$2210^{\mathrm{T}}$; All Russian Collection of Microorganisms, Pushchino, Moscow Region).

\section{ACKNOWLEDGEMENTS}

We thank Dr Elena N. Krasilnikova for performing enzyme measurements and Dr B. J. Tindall for helpful discussion. We also thank Ivan Berg for assistance in preparing this manuscript. This work was supported by grants from Russian Foundation for Basic Research (99-04-48360, 9904-49087) and by a 'Biodiversity' grant.

\section{REFERENCES}

Achenbach-Richter, L., Gupta, R., Stetter, K. O. \& Woese, C. R. (1987). Were the original eubacteria thermophiles? Syst Appl Microbiol 9, 34-39.

Brodsky, L. I., Drachev, R. L., Tatuzov, G. A. \& Chumakov, K. M. (1991). GENEBEE: package of programs for biopolymer sequence analysis. Biopolymers Cell 7, 10-14.

Castenholz, R. W. \& Pierson, B. K. (1981). Isolation of members of the family Chloroflexaceae. In The Procaryotes, pp. 291-298. Edited by P. Starr, H. Stolp, H. G. Trüper, A. Balows \& H. G. Schlegel. Berlin: Springer.

Chumakov, K. M. \& Yushmanov, S. V. (1988). Maximum topological similarity principle in molecular systematics. Mol Gen Microbiol Virusol 3, 3-9. 
Collins, M. D. (1985). Analysis of isoprenoid quinones. Methods Microbiol 18, 329-363.

Corpet, F. (1988). Multiple sequence alignment with hierarchical clustering. Syst Appl Microbiol 16, 10881-10890.

De Soete, G. (1983). A least squares algorithm for fitting additive trees to proximity data. Psychometrika 48, 621-626.

Evans, M. C. W., Buchanan, B. B. \& Arnon, D. I. (1966). A new ferredoxin-dependent carbon reduction cycle in a photosynthetic bacterium. Proc Natl Acad Sci USA 55, 928-934.

Felsenstein, J. (1989). PHYLIP - phylogeny inference package (version 3.2). Cladistics 5, 164-166.

Ferris, M. J., Muyzer, G. \& Ward, D. M. (1996). Denaturing gradient gel electrophoresis profiles of $16 \mathrm{~S}$ rRNA-defined populations inhabiting a hot spring microbial mat community. Appl Environ Microbiol 62, 340-346.

Gibson, J., Ludwig, W., Stackebrandt, E. \& Woese, C. R. (1985). The phylogeny of the green photosynthetic bacteria: absence of a close relationship between Chlorobium and Chloroflexus. Syst Appl Microbiol 6, 152-156.

Giovannoni, S., Rappe, M. S., Vergin, K. L. \& Adair, N. (1996). 16S rRNA genes reveal stratified open ocean bacterioplankton populations related to the green non-sulfur bacteria. Proc Natl Acad Sci USA 93, 7979-7984.

Gorlenko, V. M. (1975). Characteristics of filamentous phototrophic bacteria from freshwater lakes. Mikrobiologiya 44, 756-758 (in Russian).

Gorlenko, V. M. \& Korotkov, S. A. (1979). Morphological and physiological features of the new filamentous gliding green bacteria Oscillochloris trichoides nov. comb. Izv Akad Nauk SSSR Ser Biol 6, 848-857 (in Russian).

Gorlenko, V. M. \& Korotkov, S. A. (1989). Oscillochloris trichoides comb. nov. In Validation of the Publication of New Names and New Combinations Previously Effectively Published Outside the IJSB, List no. 31. Int J Syst Bacteriol 39, 495-497.

Gorlenko, V. M. \& Pivovarova, T. A. (1977). On the belonging of blue-green alga Oscillaloria coerulescens Gicklhorn, 1921 to a new genus of chlorobacteria Oscillochloris nov. gen. Izv Akad Nauk SSSR Ser Biol 3, 396-409 (in Russian).

Gorlenko, V. M. \& Pivovarova, T. A. (1989). Oscillochloris gen. nov. and Oscillochloris chrysea comb. nov. In Validation of the Publication of New Names and New Combinations Previously Effectively Published Outside the IJSB, List no. 31. Int J Syst Bacteriol 39, 495-497.

Hanada, S., Hiraishi, A., Shimada, K. \& Matsuura, K. (1995). Chloroflexus aggregans sp. nov., a filamentous phototrophic bacterium which forms dense cell aggregates by active gliding movement. Int J Syst Bacteriol 45, 676-681.

Imhoff, J. F. (1988). Lipids, fatty acids and quinones in taxonomy and phylogeny of anoxygenic phototrophic bacteria. In Green Photosynthetic Bacteria, pp. 223-232. Edited by J. M. Olson, J. G. Ormerod \& J. Amesz. New York: Plenum.

Imhoff, J. F. \& Bias-Imhoff, U. (1995). Lipids, quinones and fatty acids of anoxygenic phototrophic bacteria. In Anoxygenic Photosynthetic Bacteria, pp. 179-205. Edited by R. E. Blankenship, M. T. Madigan \& C. E. Bauer. Dordrecht: Kluwer.

Imhoff, J. F. \& Suling, J. (1996). The phylogenetic relationship among Ectothiorhodospiraceae: a reevolution of their taxonomy on the basis of $16 \mathrm{~S}$ rDNA analyses. Arch Microbiol 165, 106-113.

Ivanovsky, R. N. (1993). Calvin cycle in a green mesophilic filamentous bacterium Oscillochloris trichoides strain DG6. In
Abstracts of EMBO Workshop on Green and Heliobacteria, Nyborg, Denmark, August 16-19, p. 42.

Ivanovsky, R. N., Krasilnikova, E. N. \& Fal, Y. I. (1993). A pathway of $\mathrm{CO}_{2}$ fixation of Chloroflexus aurantiacus. Arch Microbiol 159, 257-264.

Ivanovsky, R. N., Fal, Y. I., Berg, I. A., Ugolkova, N. V., Krasilnikova, E. N., Keppen, O. I., Zakharchuc, L. M. \& Zyakun, A. M. (1999). Evidence for the presence of the reductive pentose phosphate cycle in a filamentous anoxygenic photosynthetic bacterium, Oscillochloris trichoides strain DG-6. Microbiology 145, 1743-1748.

Jukes, T. H. \& Cantor, C. R. (1969). Evolution of protein molecules. In Mammalian Protein Metabolism, vol. 3, pp. 21-132. Edited by H. N. Munro. New York: Academic Press.

Keppen, O.I. \& Krasilnikova, E. N. (1995). The activity of tricarboxylic acid cycle enzymes in Oscillochloris trichoides. Mikrobiologiya 64, 714-715 (in Russian).

Keppen, O. I., Lebedeva, N. V., Troshina, O. Yu. \& Rodionov, Yu. V. (1989). The nitrogenase activity of filamentous phototrophic green bacterium. Mikrobiologiya 58, 520-521 (in Russian).

Keppen, O. I., Baulina, O. I., Lysenko, A. M. \& Kondratieva, E. N. (1993). A new green bacterium of the family Chloroflexaceae. Mikrobiologiya 62, 267-275 (in Russian).

Keppen, O. I., Baulina, O. I. \& Kondratieva, E. N. (1994). Oscillochloris trichoides neotype strain DG-6. Photosynth Res 41, 29-33.

Krasilnikova, E. N., Keppen, O. I., Gorlenko, V. M. \& Kondratieva, E. N. (1986). Chloroflexus aurantiacus growth in media with different organic compounds and the pathways of their metabolism. Mikrobiologiya 55, 425-430 (in Russian).

Lane, D. J. (1991). 16S/23S rRNA sequencing. In Nucleic Acid Techniques in Bacterial Systematics, pp. 115-147. Edited by E. Stackebrandt \& M. Goodfellow. New York: Wiley.

Lapage, S. P., Sneath, P. H. A., Lessel, E. F., Skerman, V. B. D., Seeliger, H. P. R. \& Clark, W. A. (editors) (1992). International Code of Nomenclature of Bacteria (1990 Revision). Bacteriological Code. Washington, DC: American Society for Microbiology.

Maymo-Gatell, X., Chien, Y., Gossett, J. M. \& Zinder, S. H. (1997). Isolation of a bacterium that reductively dechlorinates tetrachloroethene to ethene. Science 276, 1568-1571.

Murzina, N. V., Vorozheykina, D. P. \& Matvienko, N. I. (1988). Nucleotide sequence of Thermus thermophilus HB8 coding 16S rRNA. Nucleic Acids Res 16, 8172.

Pfennig, N. (1989). Multicellular filamentous green bacteria. In Bergey's Manual of Systematic Bacteriology, vol. 3, pp. 1697-1707. Edited by J. T. Staley, M. P. Briant, N. Pfennig \& J. G. Holt. Baltimore: Williams \& Wilkins.

Pierson, B. K. \& Castenholz, R. W. (1974). Chloroflexus aurantiacus gen. and sp. nov. Arch Microbiol 100, 5-24.

Pierson, B. K. \& Castenholz, R. W. (1995). Taxonomy and physiology of filamentous anoxygenic phototrophs. In Anoxygenic Photosynthetic Bacteria, pp. 17-30. Edited by R. E. Blankenship, M. T. Madigan \& C. E. Bauer. Dordrecht: Kluwer.

Pierson, B. K., Valdez, D., Larsen, M., Morgan, E. \& Mack, E. E. (1994). Chloroflexus-like organisms from marine and hypersaline environments: distribution and diversity. Photosynth Res 41, 35-52.

Rainey, F. A., Zhilina, T. N., Boulygina, E. S., Stackebrandt, E., Tourova, T. P. \& Zavarzin, G. A. (1995). The taxonomic status of fermentative halophilic anaerobic bacteria: description of 
Haloanaerobiales ord. nov., Halobacteroidaceae fam. nov., Orenia gen. nov. and further taxonomic rearrangements at the genus and species level. Anaerobe 1, 185-199.

Saitou, N. \& Nei, M. (1987). The neighbor-joining method: a new method for constructing phylogenetic trees. Mol Biol Evol 4, 406-425.

Stackebrandt, E., Rainey, F. A. \& Ward-Rainey, N. (1996). Anoxygenic phototrophy across the phylogenetic spectrum: current understanding and future perspectives. Arch Microbiol 166, 211-223

Strauss, G. \& Fuchs, G. (1993). Enzymes of a novel autotrophic $\mathrm{CO}_{2}$ fixation pathway in the phototrophic bacterium Chloroflexus aurantiacus: the 3-hydroxypropionate cycle. Eur $J$ Biochem 215, 633-643.

Swofford, D. L. \& Olsen, G. J. (1990). Phylogeny reconstruction. In Molecular Systematics, pp. 411-501. Edited by D. M. Hillis \& C. Moritz. Sunderland: Sinauer.

Trüper, H. G. (1976). Higher taxa of the phototrophic bacteria: Chloroflexaceae fam. nov., family for the gliding, filamentous, phototrophic green bacteria. Int J Syst Bacteriol 26, 74-75.

Van de Peer, Y. \& De Wachter, R. (1994). TREECON for Windows: a software package for the construction and drawing of evolutionary trees for the Microsoft Windows environment. CABIOS 10, 569-570.

Ward, D. M., Bateson, M. M., Weller, R. \& Ruff-Roberts, A. L. (1992). Ribosomal RNA analysis of microorganisms as they occur in nature. Adv Microb Ecol 12, 219-286.

Weller, R., Weller, J. W. \& Ward, D. M. (1991). 16S rRNA sequences of uncultivated hot spring. Appl Environ Microbiol 57, 1146-1151.

Weller, R., Bateson, M. M., Heimbuch, B. K., Kopczynski, E. D. \& Ward, D. M. (1992). Uncultivated cyanobacteria, Chloroflexuslike inhabitants and spirochete-like inhabitants of a hot spring microbial mat. Appl Environ Microbiol 58, 3964-3969.

Woese, C. R. (1987). Bacterial evolution. Microbiol Rev 51, 221-271.

Woese, C. R., Achenbach, L., Rouvière, P. \& Mandelco, L. (1991). Archaeal phylogeny: re-examination of the phylogenetic position of Archaeoglobus fulgidus in light of certain compositioninduced artifacts. Syst Appl Microbiol 14, 364-371.

Zhilina, T. N., Zavarzin, G. A., Rainey, F. A., Pikuta, E. V., Osipov, G. A. \& Kostrikina, N. A. (1997). Desulfonatronovibrio hydrogenovorans gen. nov., an alkaliphilic sulfate-reducing bacterium. Int J Syst Bacteriol 47, 144-149. 